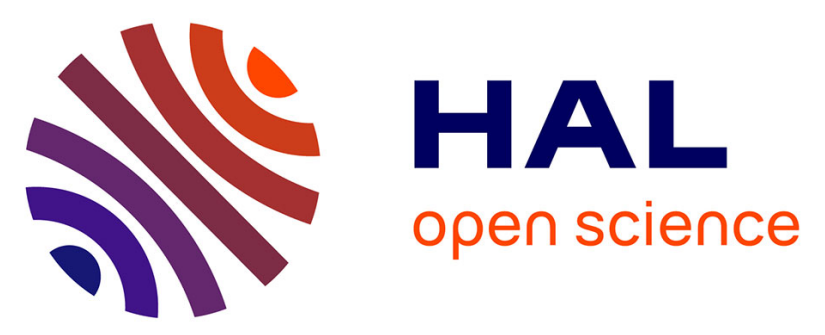

\title{
A role for pectin de-methylesterification in a developmentally regulated growth acceleration in dark-grown Arabidopsis hypocotyls
}

Sandra Pelletier, Juergen van Orden, Sebastian Wolf, Kris Vissenberg, Julien Delacourt, Yves Placide Assoumou Ndong, Jérome Pelloux, Volker Bischoff, Aurelie Urbain, Gregory Mouille, et al.

\section{To cite this version:}

Sandra Pelletier, Juergen van Orden, Sebastian Wolf, Kris Vissenberg, Julien Delacourt, et al.. A role for pectin de-methylesterification in a developmentally regulated growth acceleration in dark-grown Arabidopsis hypocotyls. New Phytologist, 2010, 188 (3), pp.726-739. 10.1111/j.14698137.2010.03409.x . hal-01203918

\section{HAL Id: hal-01203918 \\ https://hal.science/hal-01203918}

Submitted on 31 May 2020

HAL is a multi-disciplinary open access archive for the deposit and dissemination of scientific research documents, whether they are published or not. The documents may come from teaching and research institutions in France or abroad, or from public or private research centers.
L'archive ouverte pluridisciplinaire HAL, est destinée au dépôt et à la diffusion de documents scientifiques de niveau recherche, publiés ou non, émanant des établissements d'enseignement et de recherche français ou étrangers, des laboratoires publics ou privés. 


\section{A role for pectin de-methylesterification in a developmentally regulated growth acceleration in dark- grown Arabidopsis hypocotyls}

Sandra Pelletier ${ }^{1,2 *}$, Jürgen Van Orden ${ }^{3 *}$, Sebastian Wolf $^{1}$, Kris Vissenberg ${ }^{3}$, Julien Delacourt ${ }^{1}$, Yves Assoumou Ndong $^{4}$, Jérôme Pelloux ${ }^{4}$, Volker Bischoff ${ }^{1}$, Aurélie Urbain ${ }^{1}$, Grégory Mouille ${ }^{1}$, Gaëtan Lemonnier ${ }^{2}$, Jean-Pierre Renou $^{2}$ and Herman Höfte ${ }^{1}$

${ }^{1}$ Institut Jean-Pierre Bourgin, UMR1318 INRA-AgroParisTech, INRA Centre de Versailles-Grignon, Route de St-Cyr (RD10), F-78026 Versailles Cedex,

France; ${ }^{2}$ Unité Mixte de Recherche de Genomique Végétale, Institut National pour la Recherche Agronomique/Centre National pour la Recherche

Scientifique, 2 rue Gaston Crémieux-CP 5708. F-91057 Évry Cedex, France; ${ }^{3}$ Plant Growth and Development, Biology Department, University of

Antwerp, Groenenborgerlaan 171, BE-2020 Antwerpen, Belgium; ${ }^{4}$ Université de Picardie-Jules Verne, Unité de Recherche EA3900-BioPI, Biologie des

Plantes et Contrôle des Insectes Ravageurs, Faculté des Sciences, Ilôt des Poulies, 33, Rue St Leu, F-80039 Amiens, France

\section{Summary}

Author for correspondence:

Herman Höfte

Tel: +33 130833390

Email: herman.hofte@versailles.inra.fr

Received: 14 May 2010

Accepted: 20 June 2010

New Phytologist (2010) 188: 726-739

doi: $10.1111 / j .1469-8137.2010 .03409 . x$

Key words: Arabidopsis thaliana, cell elongation, cell wall, cellulose, Fourier transform infrared (FT-IR)

microspectroscopy, hypocotyl, pectin de-methylesterification, transcriptome.
- We focused on a developmentally regulated growth acceleration in the darkgrown Arabidopsis hypocotyl to study the role of changes in cell wall metabolism in the control of cell elongation.

- To this end, precise transcriptome analysis on dissected dark-grown hypocotyls, Fourier transform infrared (FT-IR) microspectroscopy and kinematic analysis were used.

- Using a cellulose synthesis inhibitor, we showed that the growth acceleration marks a developmental transition during which growth becomes uncoupled from cellulose synthesis. We next investigated the cellular changes that take place during this transition. FT-IR microspectroscopy revealed significant changes in cell wall composition during, but not after, the growth acceleration. Transcriptome analysis suggested a role for cell wall remodeling, in particular pectin modification, in this growth acceleration. This was confirmed by the overexpression of a pectin methylesterase inhibitor, which caused a delay in the growth acceleration.

- This study shows that the acceleration of cell elongation marks a developmental transition in dark-grown hypocotyl cells and supports a role for pectin de-methylesterification in the timing of this event.

\section{Introduction}

The growth of plant organs is controlled by complex regulatory networks that integrate numerous endogenous and environmental stimuli. Much progress has been made in recent years in our understanding of these regulatory networks (Nemhauser et al., 2006). However, very little is known on how they are translated into changes in cell expansion behavior. Cell expansion is turgor driven and in most cases regulated through changes in the extensibility of the primary cell wall (Taiz, 1984). The wall of growing cells is a

*These authors contributed equally to this work. fiber-enforced composite material consisting of cellulose microfibrils in a matrix of xyloglucan, pectin and structural proteins (Carpita \& McCann, 2000). Xyloglucans strongly interact with cellulose through hydrogen bonds and thus constitute a load-bearing network. Pectins are composed of blocks of complex polysaccharides characterized by the presence of negatively charged galacturonic acid. The pectin matrix controls wall hydration, porosity and, presumably, the accessibility of wall-modifying enzymes to their substrates, as well as the adhesion between cells (Willats et al., 2001a). Pectins show large structural variations during development (Willats et al., 1999) including changes in the degree of methyl- and acetyl-esterification of homogalacturonan (HG) 
blocks (Willats et al., 2001b). The degree of HG methylesterification is controlled by wall-bound pectin methylesterases (PME), which in turn can be inhibited by endogenous PME-inhibitors (PMEI). De-methylesterified HG can form $\mathrm{Ca}^{2+}$-crosslinks and thus lead to wall stiffening. At the same time de-methylesterification renders HG susceptible to hydrolysis by wall-located polygalacturonases and pectate lyases, and thus can initiate pectin cleavage and/or turnover (Willats et al., 2001b). Pectin de-methylesterification has been shown to play a critical role in pollen tube growth (Wolf et al., 2009) and in the initiation of organ primordia in the Arabidopsis inflorescence meristem (Peaucelle et al., 2008).

These examples show that the growing cell wall is a highly complex dynamic system. Given the large number of structural proteins, biosynthetic enzymes and cell wall-modifying agents, which often are encoded by large gene families, there are a large number of potential targets for the modification of the viscoplastic behavior of the cell wall. A major challenge will be to identify the actual targets of growth regulators.

A first step towards this goal is to correlate changes in gene expression with precise changes in cell expansion rate. In this study we used the Arabidopsis hypocotyl grown in the dark to study cell elongation. The hypocotyl is a simple organ of embryonic origin, the elongation of which does not depend on cell divisions (Gendreau et al., 1997). We have previously observed that cell expansion in the dark-grown hypocotyl is biphasic. Upon germination, all hypocotyl cells elongate slowly and synchronously until $48 \mathrm{~h}$ after the induction of germination. Beyond this time-point, the relative elemental growth rate (REGR) (Silk \& Erickson, 1979) of cells closest to the hypocotyl base abruptly increase four- to five-fold (Refrégier $e t$ al., 2004) This growth acceleration propagates rapidly as a wave from the base to the top of the hypocotyl. Interestingly, during the slow growth phase, a thick (Derbyshire et al., 2007a) and multilamellate (Refrégier et al., 2004) wall is deposited. This wall is massively remodeled during the growth acceleration. As a result, when growth ceases, cell walls are up to fivefold thinner than during the slow growth phase and contain mainly axially oriented polysaccharides (Refrégier et al., 2004; Anderson et al., 2009). In this study, we first used the cellulose synthesis inhibitor isoxaben to show that the regulation of cell elongation of hypocotyl cells is qualitatively different before and after the growth acceleration. During the slow growth phase, cell elongation was tightly coupled to cellulose synthesis whereas during the rapid growth phase, cells were essentially insensitive to the inhibition of cellulose synthesis by isoxaben. As part of our aim to understand the mechanism underlying this biphasic growth pattern, we studied cell wall changes and genome-wide changes in gene expression within the hypocotyl over a 10-h interval straddling the growth acceleration. This analysis provided valuable cell elongation markers and showed that the developmental transition depends on pectin de-methylesterification.

\section{Materials and Methods}

\section{Plant material and growth conditions}

Arabidopsis seeds cv Columbia were grown on solid nutrient agar medium without sucrose (Fagard et al., 2000). The germination was induced, after $3 \mathrm{~d}$ of cold treatment $\left(4^{\circ} \mathrm{C}\right)$, with fluorescent white light $\left(150 \mu \mathrm{M} \mathrm{m}^{-2} \mathrm{~s}^{-1}\right.$, True Light; Philips, Eindhoven, the Netherlands) for $4 \mathrm{~h}$ at $20^{\circ} \mathrm{C}$. The transfer to light is referred to as 'induction' and considered $t=0$ for all the experiments. The Petri dishes were then wrapped in three layers of aluminum foil and incubated under constant conditions $\left(20^{\circ} \mathrm{C}, 70 \%\right.$ humidity) in a growth cabinet (MLR 350H; Sanyo, Tokyo, Japan).

\section{Time lapse imaging}

Seeds were aligned on a square Petri dish with the micropyle oriented towards the bottom of the vertically-oriented plate and covered with a nylon mesh (NITEX 03-31/24, I OO4 M; Sefar, Thal, Switzerland) to maintain the seedlings within the focal plane. After $2 \mathrm{~d}$ stratification at $4^{\circ} \mathrm{C}$ and induction for $3 \mathrm{~h}$ in white light $\left(200 \mu \mathrm{M} \mathrm{m}^{-2} \mathrm{~s}^{-1}\right)$, the plates were wrapped in three layers of aluminum foil and incubated for $24 \mathrm{~h}$ in a culture room at $20^{\circ} \mathrm{C}, 70 \%$ humidity. Thereafter, the growth of the dark-grown seedlings was followed under Infrared light from two LED sources (IR10; Voltek Automation Ltd, Nelson, UK), using a Nikon D70 camera, equipped with a $50 \mathrm{~mm}$ macro-objective and computer piloted using the time-lapse program provided with the camera. Images were captured every $10 \mathrm{~min}$, starting at $41 \mathrm{~h}$ after induction (hpi), through the bottom of the vertically oriented Petri dish. Seedling length was measured using IMAGEJ software ( http://rsb.info.nih.gov/ij/).

\section{Microarray analysis}

Hypocotyls were harvested under green safe light at 45, 48, 52 and 55 hpi. Roots and cotyledons were removed with a scalpel and hypocotyls were immediately stored in TRIzol reagent (Invitrogen, Carlsbad, CA, USA). The sampling was performed at identical time points and did not exceed $15 \mathrm{~min}$ in order to avoid stress and variation related to the circadian rhythm. For each time-point, 250 hypocotyls, in total from 10 independent biological replicates (25 seedlings per repeat), were collected, pooled and analysed in two dye swaps that is four hybridizations per comparison (Peng et al., 2003). Total RNA was extracted from these samples using TRIzol extraction (Invitrogen) followed by two ethanol precipitations. RNA quantification and quality were assessed with the Agilent Bioanalyser (Waldbronn, Germany). Microarray hybridizations were carried out with the CATMA array (Crowe et al., 2003; Hilson et al., 2004), which contains 24576 gene-specific tags (Thareau 
et al., 2003), corresponding to 22089 genes as described in Lurin et al. (2004). This transcript profiling resource has proven its reliability in over 40 publications over the last 5 yr (ex. (Hematy et al., 2007; Achard et al., 2008; BessonBard et al., 2009; Krinke et al., 2009). In brief, cRNAs were produced from $1 \mu \mathrm{g}$ of total RNA with the 'MessageAmp cRNA' kit (Ambion, Austin, TX, USA). Then, $5 \mu \mathrm{g}$ of cRNAs was reverse transcribed in the presence of $200 \mathrm{U}$ of SuperScript II (Invitrogen), CY3-dUTP and CY5-dUTP (NEN, Boston, MA, USA). Samples were combined, purified and concentrated on YM30 Microcon columns (Millipore). Slides were pre-hybridized for $1 \mathrm{~h}$ and hybridized overnight at $42^{\circ} \mathrm{C}$ in $25 \%$ formamide. For each comparison two technical replicates with fluorochrome reversal were performed for each pool of RNA (i.e. two dye swaps) to remove dye biases. The arrays were scanned on a GenePix 4000 A scanner (Axon Instruments, Foster City, CA, USA) at constant PMT, and images were analysed by GENEPIX PRO 3.0 (Axon Instruments).

Normalization and statistical analysis was based on two dye swaps per comparison (i.e. four arrays, each containing 24576 GSTs and 384 controls) as described in Gagnot $e t$ al. (2008). The methods are available in the R package 'Anapuce' (http://cran.r-project.org/web/packages/anapuce/index.html). First, a normalization per array is performed to remove systematic biases, without background substraction. Then, a global intensity dependent normalization is performed using the LOWESS procedures (Yang et al., 2002) to correct the dye bias. Finally, for each block, the log-ratio median calculated over the values for the entire block is subtracted from each individual $\log$ ratio value to correct effects on each block, as well as print-tip, washing and/or drying effects. To determine differentially expressed genes from a dye-swap, a paired $t$-test is performed on the $\log _{2}$-ratios, with a common variance for all the genes ( $H$ homoscedasticity), leading to a robust estimation of the variance and a high power of the test. Spots with an extreme variance or genes for which one observation only is available are excluded. Then, the raw $P$-values are adjusted by the Bonferroni method, which controls the family-wise error rate (FWER) (Ge et al., 2003). In this study we focused on the genes with a Bonferroni $P$-value $\leq 0.0001$ in order to ensure a very high significance of the deregulation measurements between each time-point.

The data were deposited in Array express (http://www. ebi.ac.uk/arrayexpress/; details listed under accession number E-MEXP-195) and in CATdb (http://urgv.evry.inra. fr/CATdb/; Project nr: RA03-04_Elongation_isoxaben) according to the 'Minimum Information About a Microarray Experiment' standards. Functional categories of differentially expressed genes were adapted from the categories defined by The Arabidopsis Information Resource (TAIR) (http://www.arabidopsis.org). Categories of cell wall genes were as defined by the Cell Wall Genomics website (http://cellwall.genomics.purdue.edu/families/index.html).
Overrepresented gene categories were calculated and displayed using the BINGO 2.0 plug-in (Maere et al., 2005) in CYTOSCAPE v2.5.1 (http://www.cytoscape.org/).

\section{Microarray data validation}

Quantitative real-time reverse-transcription polymerase chain reaction (RT-PCR) validation was performed for 30 genes with various expression patterns and levels. The primers for RT-PCR were selected using PRIMER3 (http://frodo. wi.mit.edu/primer3/, optimal length $21 \mathrm{nt}$, optimal Tm $60^{\circ} \mathrm{C}$ ). Electronic-PCR (ftp://ncbi.nlm.nih.gov/pub/schuler/ e-PCR/) was used to check for single band and correct size amplification from the Arabidopsis genome. All the selected primers matched these requirements. The primer pairs were first tested on dilution series of genomic DNA (5 ng, $0.5 \mathrm{ng}, 0.05 \mathrm{ng}, 0.005 \mathrm{ng}$ ) to generate a standard curve and assess their PCR efficiency which was between $90 \%$ and $99 \%$. For each point, hypocotyls of 475 seedlings of 16 independent biological replicates were collected and total RNA was extracted as described in the microarray procedures paragraph. The samples were treated by DnaseI (Invitrogen) following the manufacturer's protocol. Reverse transcription was performed on $1 \mu \mathrm{g}$ of total RNA using an oligodT primer $(18 \mathrm{mer})$ and the Superscript II reverse transcriptase (Invitrogen), for $1 \mathrm{~h}$ at $42^{\circ} \mathrm{C}$ in $40 \mu \mathrm{l}$. The enzyme was then heat-inactivated at $65^{\circ} \mathrm{C}$ and the samples were treated with RNase $\mathrm{H}$. Quantitative PCR reactions were performed in $15 \mu \mathrm{l}$, using $0.1 \mu \mathrm{lng}$ of RT reaction, $900 \mathrm{nM}$ final concentration of each primer pair and SYBRGreen PCR master mix 2X (Eurogentec, Angers, France). Corresponding minus RT controls were performed with each primer pairs. Conditions were as follows: $95^{\circ} \mathrm{C} 10 \mathrm{~min}, 40 \mathrm{X}\left(95^{\circ} \mathrm{C} 15 \mathrm{~s}\right.$, $60^{\circ} \mathrm{C} 1 \mathrm{~min}$ ) and a dissociation step, that allows discrimination between primer dimers and PCR product. All reactions were performed in RT duplicate with the ABI PRISM 7900HT Sequence Detection System (Applied Biosystem) and data were analysed with the SDS software provided by the manufacturer. The PCR products were visualized on $2.0 \%$ agarose gel stained with ethidium bromide, to check the amplicon size. Four house-keeping genes were used for normalization At1g16460, At4g24820, At5g11770 and At5g46290.

\section{FT-IR microspectroscopy}

For each point 50 seedlings of 8 independent biological replicates were collected. Seedlings were squashed between two $\mathrm{BaF}_{2}$ windows and rinsed thoroughly in distilled water for $2 \mathrm{~min}$. The samples were then dried on the window at $37^{\circ} \mathrm{C}$ for $20 \mathrm{~min}$. An area of $50 \mu \mathrm{m} \times 50 \mu \mathrm{m}$ at the base and at the top of each hypocotyl on the side of the central cylinder was selected for FT-IR microspectroscopy. A ThermoNicolet Nexus spectrometer equipped with a Continu $\mu \mathrm{m}$ 
microscope accessory (Thermo scientific, Courtaboeuf, France) was used. Fifty interferograms were collected in transmission mode, with $8 \mathrm{~cm}^{-1}$ resolution, and co-added to improve the signal-to-noise ratio. The collected spectra were baseline corrected and normalized as described in Mouille et al. (2003). Raw data are available upon request.

\section{Plasmid construction}

DNA was extracted from Arabidopsis thaliana Col0 leaves with a plant DNA mini kit (Omega-biotek, http:// www.omegabiotek.com). To clone the promoter region of At4g25250 (PMEI), a fragment 750 bp upstream of the start codon was PCR-amplified with primers 5'-GGGGACCACTTTGTACAAGAAAGCTGGGTTGGATTTAGATGAAGTGGAAATAAG-3', promPMEIfor 5'-GGGGACAAGTTTGTACAAAAAAGCAGGCTCGATATCATTGTTAAACTTGCCATC- ${ }^{\prime}$ and promPMEIrev 5'-GGGGACCACTTTGTACAAGAAAGCTGGGTTGTGAACTATGGTTTATGTGTATATGTATA- $3^{\prime}$ containing the AttB Gateway recombination sites. The PCR fragment was cloned into pDONR207 (Invitrogen, http://www.invitrogen.com) with BP clonase (Invitrogen) according to the manufacturer's protocol. The LR clonase reaction was carried out with pGWB3 and pGWB4, generating the binary plasmid pPMEI:GUS and pPMEI:GFP respectively, which were then transformed into Agrobacterium tumefaciens C58 (pMP90). Arabidopsis thaliana Col0 was transformed using the floral dip method (Bechtold \& Pelletier, 1998). Transgenic lines were selected on MS medium (Murashige \& Skoog, 1962) containing $50 \mathrm{mg} / \mathrm{l}$ kanamycin. To generate plants overexpressing PMEI4, the open reading frame (ORF) of PMEI4 was amplified via PCR using genomic DNA and gene-specific primers (GSPs) 35spmeifor 5'-ATGTTGCGTTTCGTGGTACTC-3' and 35spmeirev 5'-TCAATAACTTAAATAATGAGTAAGAAGGGCTAAAG- ${ }^{\prime}$. Gateway recombination sites were added to clone the PCR product into the gateway-compatible vector pDONR207 with BP clonase (Invitrogen). After sequencing, the ORF was cloned in the destination vector pH2GW7 (Karimi et al., 2002) with LR clonase following the manufacturer's instructions (Invitrogen). To generate 35S:PMEI4::GFP, the ORF of PMEI4 was amplified using forward primer 35 spmeifor and reverse primer 35spmeirevgfp 5'-ATAACTTAAATAATGAGTAAGAAGGGCTAAAG- $3^{\prime}$. The reverse primer does not contain the stop codon to generate a translational fusion gene with GFP. After cloning this PCR product into pDONR207, the ORF was cloned into pGWB5 to generate a $C$-terminal fusion gene. To construct pPMEI4::GFP, the genomic sequence $750 \mathrm{bp}$ upstream of the ATG start codon together with the ORF was amplified with forward primer promPMEIfor 5'-CGATATCATTGTTAAACTTGCCATC- $3^{\prime}$ and reverse primer 35 spmeirevgfp and after cloning into pDONR207, the complete fragment was cloned into the destination vector pGWB4 generating a $C$-terminal fusion gene under the control of his own promotor. All constructs were transformed into A. tumefaciens C58C1 (pMP90) (Koncz \& Schell, 1986). 35S:PMEI was selected on half-strength MS medium (Murashige \& Skoog, 1962) containing hygromycin and the translational fusion genes and promoter reporter constructs were selected on kanamycin. The $\mathrm{F}_{2}$ homozygous transgenic progeny was obtained after self-fertilizing and selection on the proper antibiotic.

For generation of at3g49220 prom:GUS lines, $2,2 \mathrm{~kb}$ of genomic DNA sequence upstream of the start codon were amplified with primers 49prom_F $5^{\prime}$-gggacaagtttgtacaaaaaagcaggctttaagctttagtttattctag- $3^{\prime}$ and 49prom_R 5'-ggggaccactttgtacaagaaagctgggttttgtttcttggtttagttctc- $3^{\prime}$ using Phusion polymerase (Finnzymes, Keilaranta, Finland). Gateway cloning (Invitrogen, Cergy-Pontoise, France) into pDONR201 and subsequently into the binary vector pBGWFS7 (Karimi et al., 2002) was performed according to the manufacturers instructions except that recombination reactions were scaled down to one-fourth of the recommended volumes. Transgenic plants were identified by repeated BASTA (Bayer Cropscience, Lyon, France) application to soil grown seedlings.

\section{Glucuronidase (GUS) staining procedure}

Seedlings were grown in the dark for the indicated times at $22^{\circ} \mathrm{C}$ after a $48 \mathrm{~h}$ stratification period at $4^{\circ} \mathrm{C}$. After fixation in $90 \%$ acetone for $2 \mathrm{~h}$ at $-20^{\circ} \mathrm{C}$, the seedlings were rinsed with GUS staining buffer without substrate $(0.1 \mathrm{M}$ $\mathrm{Na}_{2} \mathrm{HPO}_{4} / \mathrm{NaH}_{2} \mathrm{PO}_{4} \mathrm{pH}$ 7, $10 \mathrm{mM}$ NaEDTA, $20 \mathrm{mM}$ $\left.\mathrm{K}_{4}\left(\mathrm{Fe}(\mathrm{CN})_{6}\right), 20 \mathrm{mM} \mathrm{K}_{3}\left(\mathrm{Fe}(\mathrm{CN})_{6}\right)\right)$. Histochemical staining of GUS activity was achieved by adding $2 \mathrm{mM}$ X-Gluc (Duchefa, Haarlem, The Netherlands) to the same buffer and incubation at $37^{\circ} \mathrm{C}$ over night.

\section{Microscopy}

Green fluorescent protein (GFP) fluorescence of pPMEI4:GFP was examined under a confocal laser scanning microscope (Nikon C1, NIKON, http://www.nikon.com). The cell surface was counterstained by incubating the seedlings in $0,1 \mathrm{mg} \mathrm{ml}^{-1}$ propidium iodide and rinsed with water. Images were taken with a Zeis Axioskop microscope equipped with a Nikon DXM 1200 digital camera. Spinning disc microscopy was carried out as described in Crowell et al. (2009).

Isolation of AtPMEI3-1, RNA extraction and quantitative RT-PCR

A gene Trap that disrupts the PMEI4 gene was obtained (SM_ 3_34502) from the Salk collection (http://signal.salk.edu). 
A PCR-based screening with forward primer 198F 5'AAACACCGGAACGAAACTTG- $3^{\prime}$ and reverse primer 198R 5'-CCATGCACATGCAAAGAGAT-3' together with transposon specific primer Spm32 5'-TACGAATAAGAG CGTCCATTTTAGAGTGA-3' was used to identify homozygous plants (http://www.jic.ac.uk/science/cdb/exotic/). Total RNA was extracted from 4-d-old hypocotyls grown in the dark using Trizol reagent (Invitrogen) following the manufacturer's protocol. Three $\mu \mathrm{g}$ of total RNA was used to make cDNA with Superscript Reverse Transcriptase III (SSRT-III; Invitrogen) and oligo-d(T) primer. The PMEI4 transcripts were quantified in knockout and overexpressing lines with the specific primers At4G25250F 5'TTGCGTTTCGTGGTACTCTC-3' and At4G25250R 5'-TAGTTTTCCCTCCGCCTCT-3' relative to the validated reference gene APT1/At1g27450 (APT1F 5'-CGGG GATTTTAAGTGGAACA-3' and APT1R 5'-GAGACATT TTGCGTGGGATT-3') in a Roche Light Cycler using an ABsolute QPCR SYBR Green Capillary Mix (Abgene, Courtaboeuf, France). Data are the means of three or four replicates. These data were exported into RelQuant software (Roche), which provides efficiency-corrected normalized quantification results.

\section{Results}

The growth acceleration marks a qualitative change in the control of cell elongation in dark-grown hypocotyls.

We previously showed that upon germination, which in our growth conditions occurred c. 24 h post-induction (pi, see 'Experimental procedures' for definition 'induction'), hypocotyls elongated with a velocity $<0.1 \mathrm{~mm} \mathrm{~h}^{-1}$. At c. $48 \mathrm{~h}$ post induction (hpi), the growth rate accelerated in a wave from the base to the top of the hypocotyl to reach a steadystate velocity of c. $0.3 \mathrm{~mm} \mathrm{~h}^{-1}$ (Refrégier et al., 2004). This rate was maintained throughout the next $3 \mathrm{~d}$ (data not shown). The Supporting Information, Figs 1 and S1, shows representative seedlings at $45 \mathrm{hpi}$ and $48 \mathrm{hpi}$ (before the growth acceleration) and at $52 \mathrm{hpi}$ and $55 \mathrm{hpi}$ (after the acceleration). Our previous observations showed qualitative

Fig. 1. Developmental transition in dark-grown hypocotyl. (a) Phenotype of wild-type dark-grown seedlings before ( $45 \mathrm{~h}$ after induction (hpi) and $48 \mathrm{hpi}$ ) and after (52 hpi and $55 \mathrm{hpi}$ ) the growth acceleration at the hypocotyl base. See also Fig. S1. (b-e) Effect of cellulose synthesis inhibitor isoxaben on hypocotyl elongation before and after growth acceleration. Distribution of hypocotyl lengths of dark-grown seedlings incubated for $4 \mathrm{~d}$ in the presence of $4 \mathrm{nM}$ isoxaben (triangle, dashed line) or on control medium (square, dotted line) and of 4-d-old dark-grown seedlings that had been transferred to $4 \mathrm{nM}$ isoxaben (circle, solid line) at $30 \mathrm{hpi} \mathrm{(b),} 45 \mathrm{hpi}$ (c), $50 \mathrm{hpi} \mathrm{(d)} \mathrm{and} 55 \mathrm{hpi}$ (e). Bar, $1 \mathrm{~mm}$. (a)
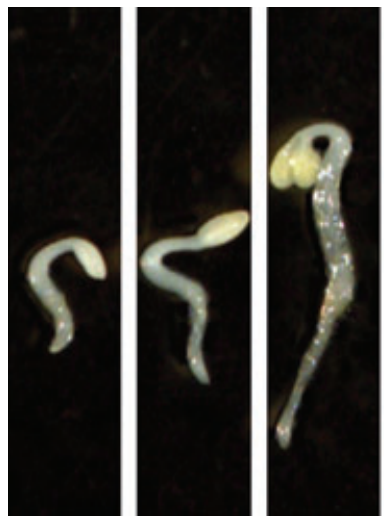

48

52
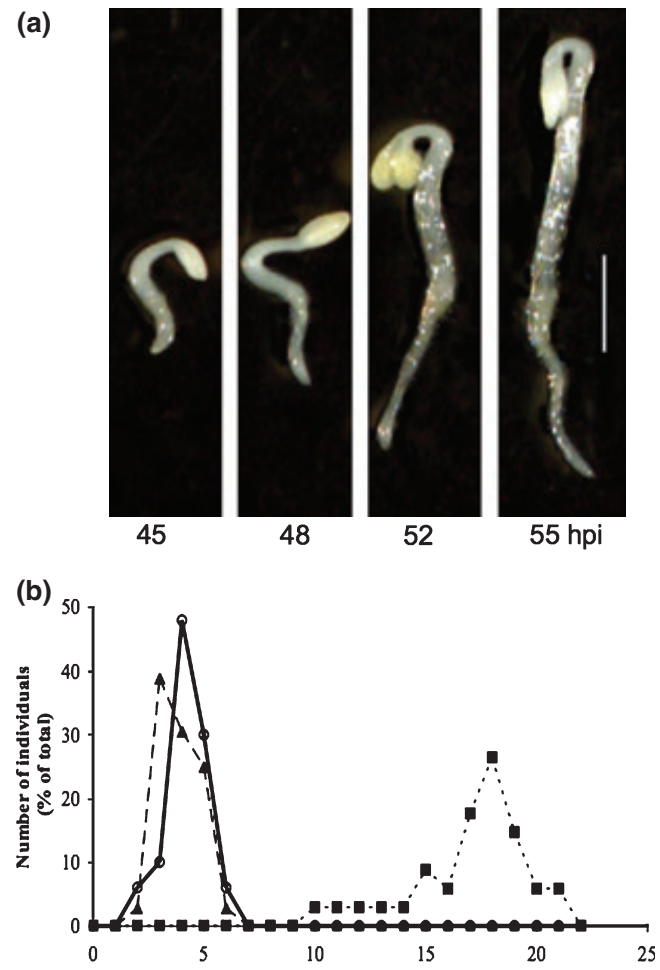

(c)
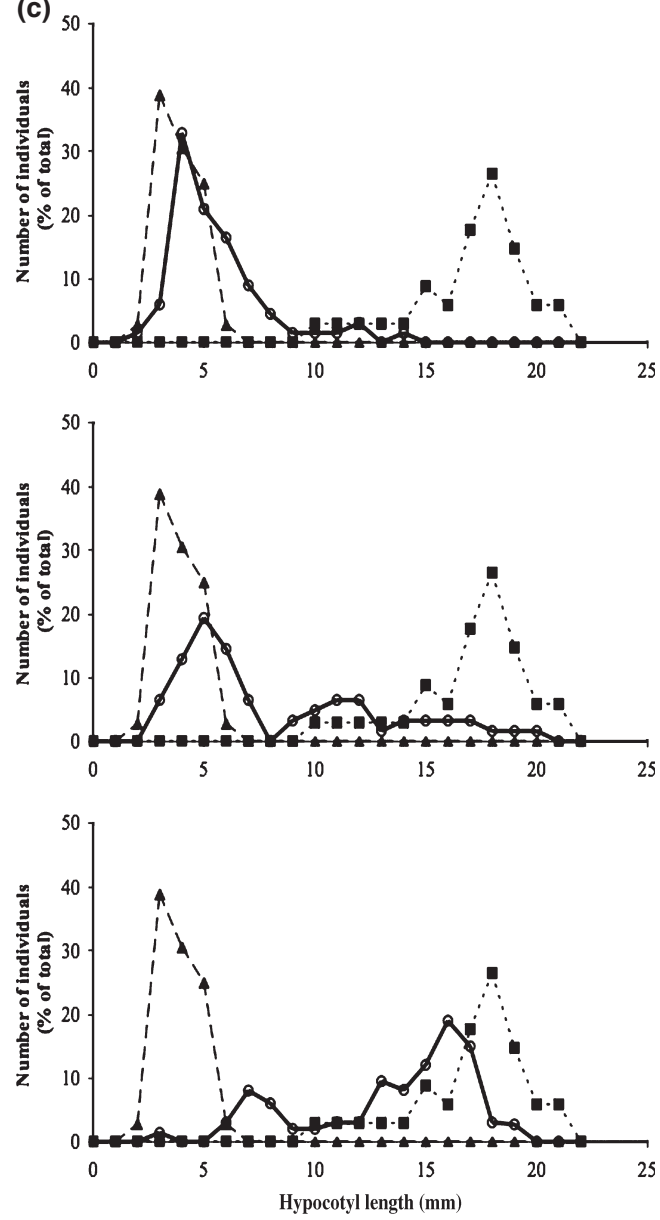
differences in the control of growth during the slow and rapid elongation phase in dark-grown hypocotyls (Refrégier et al., 2004). Indeed, isoxaben treatment before $30 \mathrm{hpi}$ inhibited the growth acceleration, whereas the same treatment after 50 hpi did not interfere with further growth, suggesting that cell elongation became uncoupled from cellulose synthesis at this stage. To investigate this in more detail, we transferred seedlings to $4 \mathrm{nM}$ isoxaben at 30, 45 , 50 and 55 hpi and measured hypocotyl length after $4 \mathrm{~d}$ (Fig. 1). Consistent with previous observations, hypocotyl growth was inhibited when transferred at 45 hpi (Fig. 1c) and only marginally in seedlings transferred at $55 \mathrm{hpi}$ (Fig. 1e) to isoxaben. At the intermediate time-point (Fig. 1d), the hypocotyl lengths of the seedling population showed a biphasic distribution suggesting that the growth acceleration was accompanied by a discrete change in the sensitivity to isoxaben. Isoxaben is thought to target directly the cellulose synthase complex (CSC) because amino acid changes in the $C$-terminus of two cellulose synthase catalytic subunits (CESA3 and CESA6) confer isoxaben-resistance to the plant (Scheible et al., 2001; Desprez et al., 2002). Like several other cellulose synthesis inhibitors, isoxaben causes the internalization of GFP-labeled CSCs into microtubulebound compartments (Crowell et al., 2009; Gutierrez et al., 2009). Interestingly, isoxaben caused the internalization of GFP-CESA3 upon a 30-min incubation both at $45 \mathrm{hpi}$ and 52 hpi (Fig. S2), indicating that after the growth acceleration, isoxaben also reached its target and inhibited cellulose synthesis. The inhibition of cellulose synthesis leads to other cellular changes such as ectopic lignin accumulation and changes in gene expression presumably through a cell wall integrity sensing system (Hematy et al., 2007). Interestingly, using CATMA transcript profiling (procedure described below) we showed that the acquisition of isoxaben-resistance after the growth acceleration was also reflected at the transcriptional level: 155 genes (134 up and 21 down) were differentially expressed between hypocotyls from seedlings treated or not treated with isoxaben between $45 \mathrm{hpi}$ and $48 \mathrm{hpi}$, whereas only 28 genes showed different transcript levels when comparing $52 \mathrm{hpi}$ and $55 \mathrm{hpi}$ (Table S1, Bonferroni $P$-value $<10^{-4}$ and Fig. S3). In the latter comparison no genes were upregulated. In addition, the intersection between the two datasets only contained two genes (changes in opposite directions for the two comparisons) confirming that the response to isoxaben was qualitatively different before and after the growth acceleration.

\section{Changes in cell wall composition associated with the growth acceleration}

We next studied the molecular events that accompany the growth transition. We used FT-IR microspectroscopy to study cell wall changes (Mouille et al., 2003) in the area of the hypocotyl that underwent the growth acceleration. As a negative control, we also sampled spectra from the cells within the apical hook of the same hypocotyls, which did not undergo a growth acceleration during this time period. Given the simple anatomy of the hypocotyl, the spectra corresponded to the absorbance of only two cell types: epidermis and cortex. Fig. 2a,b show an average spectrum and a Student's $t$-test on the comparison of the average spectra sampled from the hypocotyl base respectively at $45 \mathrm{hpi}$ and $48 \mathrm{hpi}$ (black trace). During this $3 \mathrm{~h}$ period, highly significant changes in the cell wall composition had taken place. One observes a significant decrease in the relative amount of carboxyl $\left(1697 \mathrm{~cm}^{-1}\right)$ and carboxyl ester $\left(>1720 \mathrm{~cm}^{-1}\right)$ $\mathrm{C}=\mathrm{O}$ stretches (http://www.muhlenberg.edu/depts/chemistry/ irexer/IRDATATB.htm\#acid), suggesting a global decrease in the relative amount of pectin, while maintaining the ratio between esterified and de-esterified pectin. The equally significant decrease in amide bonds $\left(1558 \mathrm{~cm}^{-1}\right.$ and $1511 \mathrm{~cm}^{-1}$ ) indicates a decrease in relative protein content. At the same time a significant increase in the polysaccharide fingerprint region had occurred, notably at 1106, 1060 and $1033 \mathrm{~cm}^{-1}$, suggesting a relative increase in cellulose and/or xyloglucan (Kacurakova et al., 2002). During the same period, no significant changes had occurred in the relative cell wall composition at the top of the hypocotyl (Fig. 2c,d, black trace). Between $48 \mathrm{hpi}$ and $52 \mathrm{hpi}$ (during the growth acceleration), again major changes could be observed in the hypocotyl base (Fig. 2b, green trace). This included a further increase in the relative cellulose and/or xyloglucan content but also changes that were qualitatively different from those occurring before the growth acceleration, such as a decrease in a discrete carboxyl ester $\mathrm{C}=\mathrm{O}$ band at $1747 \mathrm{~cm}^{-1}$, without a change in the relative amount of carboxylic acid. This suggests a decrease in the degree of methylesterification of pectins combined with the turnover of the newly de-esterified pectin. Again, except for minor peaks at $1130 \mathrm{~cm}^{-1}$ and $1747 \mathrm{~cm}^{-1}$, no significant changes were observed at the top of the hypocotyl (Fig. 2a, green trace). Between $52 \mathrm{hpi}$ and $55 \mathrm{hpi}$, cells at the base had reached a new steady state growth rate (Refrégier $e t$ al., 2004). During this period, we did not observe significant changes in the relative cell wall composition at the top or at the base of the hypocotyl, suggesting that the cell wall composition also had reached a new steady state (Fig. 2b,d, blue trace).

In conclusion, the ratio between cell wall polymers remained relatively unchanged in cells with a constant growth rate, as found at the top of the hypocotyl or in cells at the base after the acceleration. By contrast, the growth transition involved significant changes in the ratio between polysaccharides. Before the transient growth acceleration, the ratio between cellulose and/or xyloglucan and pectin increased. During the growth acceleration, the relative cellulose and/or xyloglucan content further increased, whereas the relative amount of ester bonds, presumably 

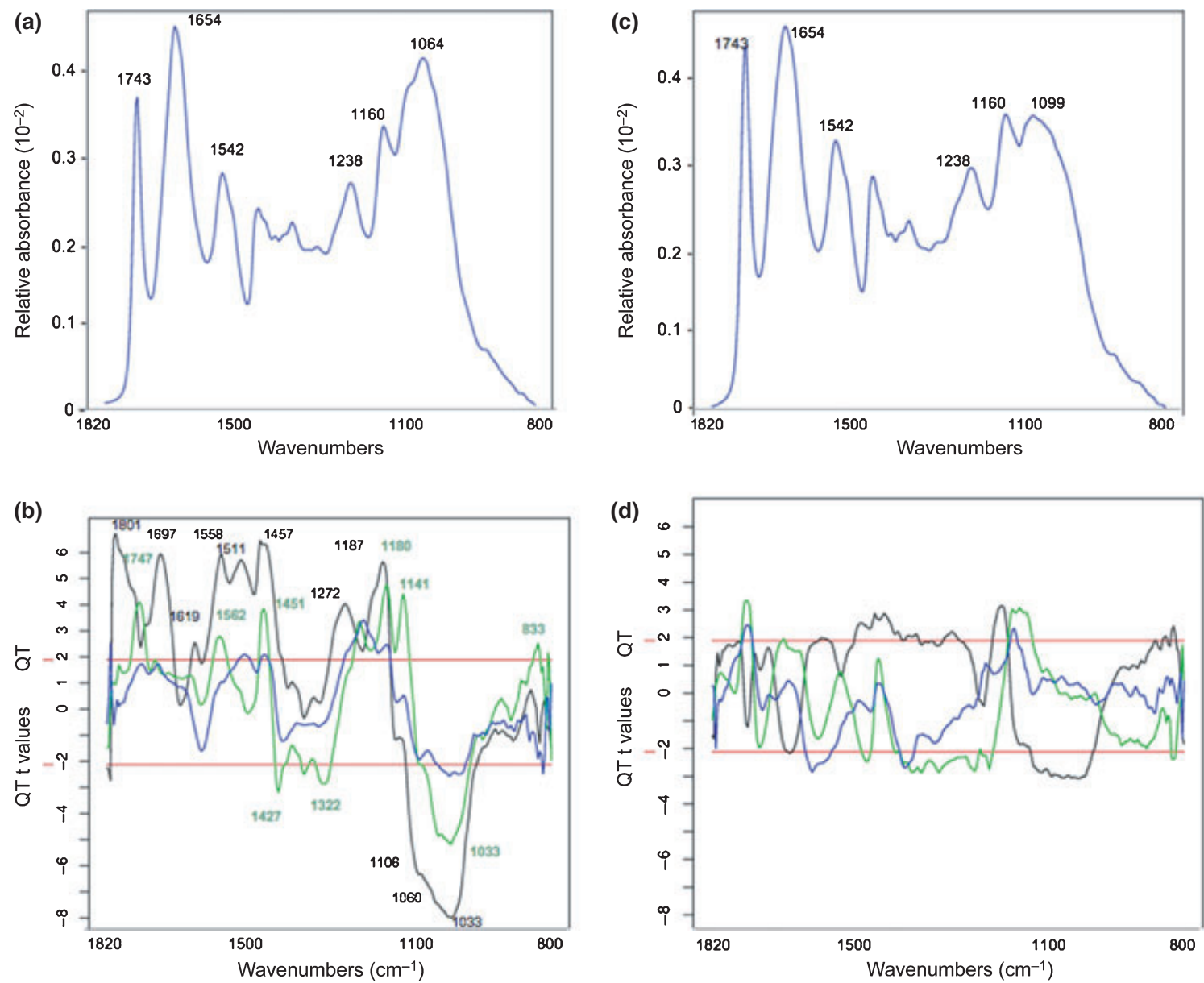

Fig. 2. Cell wall changes before and during growth acceleration. (a-d) Fourier transform infrared (FT-IR) microspectroscopy reveals significant changes in cell wall composition before, during but not after the growth acceleration. $(\mathrm{a}, \mathrm{c})$ Average FT-IR spectra $\left(800-1800 \mathrm{~cm}^{-1}\right) \mathrm{from}$ base (a) and top (c) of dark-grown hypocotyl. (b,d) Student's $t$-test $(P=0.05)$ of comparison of FT-IR spectra sampled from the bottom (b) and the top (d). Comparison between $45 \mathrm{~h} / 48 \mathrm{~h}$ after induction (hpi) (black trace, for $t$-values $>2$, absorbance for corresponding wavenumber is significantly higher at $45 \mathrm{hpi}$ compared with $48 \mathrm{hpi}$ ), $48 \mathrm{~h} / 52 \mathrm{hpi}$ (green trace) and $52 \mathrm{~h} / 55 \mathrm{hpi}$ (blue trace). Horizontal red lines mark the $P=0.01$ significance level. Wavenumbers corresponding to most important peaks are shown in (a) and (c). Wavenumbers corresponding to significantly different absorbance intensities are indicated in (b).

corresponding to methylesterified pectin, decreased accompanied by other, as yet, uncharacterized changes in cell wall composition. These changes are consistent with the previously observed massive deposition of cellulose during this period (Refrégier et al., 2004) and the upregulation of transcripts encoding pectin-metabolizing enzymes within the same developmental window (see next paragraph).

\section{Changes in gene expression associated with the growth acceleration}

To monitor the changes in gene expression associated with the growth acceleration, hypocotyls were dissected under green safe light from seedlings at 45, 48, 52 and $55 \mathrm{hpi}$, while avoiding seedlings that were delayed in their germination. Three comparisons were analysed using CATMA microarrays (Crowe et al., 2003; Hilson et al., 2004):
48 hpi vs 45 hpi (a positive signal indicating that the transcript level was higher at $48 \mathrm{hpi}$ than at $45 \mathrm{hpi}$ ), $52 \mathrm{hpi}$ vs 48 hpi and 55 hpi vs 52 hpi, respectively, before, during and after the growth acceleration of the cells at the hypocotyl base, following the design shown in Fig. S3a. Among 22089 genes on the microarray, 870 showed significant changes in transcript levels according to the Bonferroni $P$-value $<10^{-4}$ (Table S1 and Fig. S3) during the 45-55 hpi period. To demonstrate the reliability of the CATMA microarray data, 30 genes were chosen for independent validation by quantitative RT-PCR on an independent set of experiments (Table S2). Although the amplitude varied in some cases, the differential transcript levels were confirmed for all genes studied. Further confirmation of the microarray data came from transgenic lines expressing promoter-GUS or promoter-GFP fusions mentioned later. 
Interestingly, most of the transcriptional changes occurred associated with the growth acceleration (48 hpi vs 52 hpi), with 594 genes differentially regulated, compared with only 66 differentially regulated genes between 45 hpi and 48 hpi. Only a small number of ontology classes were significantly overrepresented among the differentially regulated genes (Fig. S4). Among the downregulated genes, only functional categories related to ribosome and cytoplasm synthesis as well as peroxidase activity were over-represented (Fig. S4). Strikingly, 20 transcripts encoding ribosomal proteins were downregulated between $48 \mathrm{hpi}$ and $55 \mathrm{hpi}$ (Table S3). Decreasing the stringency of the Bonferroni cut off $P$-value to $5 \%$, increased the number of downregulated ribosomal protein transcripts to 56 (http://urgv.evry.inra.fr/ CATdb/; Project nr: RA03-04_Elongation_isoxaben). The downregulation of ribosomal protein genes suggests that, paradoxically, cytoplasm synthesis had slowed down in a large subpopulation of cells very early after the growth acceleration, at a time when the hypocotyl length had barely exceeded $2 \mathrm{~mm}$ compared with the almost $2 \mathrm{~cm}$ that can be reached at the end of the growth period (Gendreau et al., 1997). Among the upregulated genes, over-represented ontology classes were restricted to chloroplast biogenesis and photosynthesis, auxin signaling, cold and water stress and cell wall-related processes (Fig. S4). The upregulation of nuclear- and chloroplast-encoded transcripts related to photosynthesis (Table 1) suggests that, despite the absence of light, at least part of the photosynthetic machinery was being put in place. Nineteen auxin-induced genes were upregulated between $45 \mathrm{hpi}$ and $55 \mathrm{hpi}$ (Table 1). These genes comprise four distinct gene families: SAUR (eight genes), IAA (six genes), AIR12-like genes (three genes) and (putative) efflux carriers (two genes). To identify components that are potentially involved in the activation of cell elongation, we focused on the upregulated cell wall-related genes (Table 1). This category included four genes encoding wall-loosening proteins expansins (Cosgrove, 1999), four genes encoding xyloglycan endotransglycosylase/ hydrolases, or XTHs (Rose et al., 2002), six genes encoding arabinogalactan proteins or AGPs (Seifert \& Roberts, 2007) and 12 genes involved in pectin modification (Table 1). For a subset of these proteins, a cell wall location was observed using cell wall proteomics on 7- and 11-d-old dark-grown hypocotyls (Irshad et al., 2008) (Table 1). The pectin modifying enzymes included four putative PMEs, four putative PMEIs, three putative pectate lyases (PL) and 1 putative polygalacturonase (PG). Promoter-reporter gene constructs for PMEI (At4g25250, discussed below) and PME (At3g49220) introduced in Arabidopsis confirmed the upregulation of the genes during the developmental transition (Fig. 3). These findings are consistent with a role for de-methylesterification and turnover of pectins in the growth acceleration, as suggested by the FT-IR data. Some PMEIs have been characterized biochemically (Wolf et al.,
2009); they bind with a $1: 1$ stoichiometry to plant PMEs and inhibit the enzyme activity. It has been suggested that they may play a role in the inhibition of PMEs within the secretory pathway or in the fine tuning of PME activity within the cell wall (Rockel et al., 2008).

\section{Pectin de-methylesterification controls the timing of the growth acceleration in dark-grown hypocotyls}

To investigate the role of pectin de-methylesterification in the growth acceleration, we set out to manipulate the PME activity in situ. The PMEs constitute a family of $66 \mathrm{mem}-$ bers in Arabidopsis (Pelloux et al., 2007), only three of which have been analysed biochemically. The four upregulated PME genes (Table 1) all encode group 2 proteins characterized by the presence of a PMEI-like pro-domain (Pelloux et al., 2007). To circumvent potential redundancy within the PME family, we used a putative PMEI to manipulate the PME activity. The PMEIs form an equally large gene family of 64 members in Arabidopsis (Wolf et al., 2009). At4g25250 is the PMEI gene that showed the strongest upregulation during the growth acceleration. The encoded protein, further referred to as PMEI4, is the Arabidopsis isoform most closely related to a biochemically characterized PMEI in pepper (An et al., 2008), suggesting that it also has PMEI activity. Consistent with the microarray data, GFP expressed from the PMEI4 upstream sequence only appeared after the growth acceleration in the hypocotyls. In addition, the expression was restricted to the epidermis (Fig. 3c-e). Interestingly, consistent with published microarray data (Birnbaum et al., 2003), GFP was also expressed in the root in rapidly elongating epidermis cells (Fig. 3b), indicating that PMEI4 can be used as a marker for epidermal cells in their rapid expansion phase in both organs. PMEI4 fused to GFP was expressed either from its own promoter (pPMEI4::GFP) or the CaMV 35S promoter (35S:PMEI4::GFP). Quantitative RT-PCR (Fig. 4a) showed that PMEI4 transcripts were undetectable in the knockout mutant pmei4-1, which confirms the specificity of the RT-PCR reaction. PMEI4 transcript levels showed a slight increase in two pPMEI4::GFP lines compared with wild type and 10-fold increase in the 35S:PMEI4::GFP line. This large difference in expression levels obtained with the 2 promoters is expected given the much more restricted expression domain of the PMEI4 promoter (epidermis) compared with the constitutive $35 \mathrm{~S}$ promoter. The FT-IR microspectroscopy on 4-d-old darkgrown hypocotyls of these lines revealed significantly higher levels of carboxylic ester $\mathrm{C}=\mathrm{O}$ bonds $\left(1712 \mathrm{~cm}^{-1}\right)$ compared with untransformed control plants (Fig. 4b), which is consistent with increased concentrations of methylesterified pectins in the transformants. Kinematic analysis was used to study the growth acceleration in dark-grown hypocotyls (Fig. 4c). Untransformed control plants and the pmei4-1 
Table 1 Upregulated genes during 45-55 h after induction (hpi) interval in dark-grown hypocotyls

\begin{tabular}{|c|c|c|c|c|c|c|c|}
\hline \multirow{2}{*}{\multicolumn{2}{|c|}{$\frac{\text { AGla Annotation }}{\text { Photosynthesis related genes }}$}} & \multicolumn{2}{|c|}{$45-48$ hpi } & \multicolumn{2}{|c|}{$48-52$ hpi } & \multicolumn{2}{|c|}{$52-55$ hpi } \\
\hline & & $\begin{array}{l}\log _{2} \\
\text { rat }\end{array}$ & $\begin{array}{l}\text { Bonferoni } \\
P \text {-value }\end{array}$ & $\begin{array}{l}\log _{2} \\
\text { rat }\end{array}$ & $\begin{array}{l}\text { Bonferoni } \\
P \text {-value }\end{array}$ & $\begin{array}{l}\log _{2} \\
\text { rat }\end{array}$ & $\begin{array}{l}\text { Bonferoni } \\
P \text {-value }\end{array}$ \\
\hline AT4G02770 & Photosystem I reaction center subunit II-1/psaD1 & 0.26 & $1.00 E+00$ & 0.73 & $5.03 E-09$ & -0.27 & $1.00 E+00$ \\
\hline AT1G79040 & Photosystem II 10 kDa polypeptide/PSBR & 0.12 & $1.00 E+00$ & 0.77 & $2.10 E-10$ & -0.12 & $1.00 E+00$ \\
\hline AT5G64040 & Photosystem I reaction center subunit N/PSAN & 0.03 & $1.00 \mathrm{E}+00$ & 0.88 & $0.00 E+00$ & 0.05 & $1.00 E+00$ \\
\hline AT4G12800 & Photosystem I reaction center subunit XI/PSAL & 0.63 & $1.94 \mathrm{E}-06$ & 0.94 & $0.00 E+00$ & $\$$ & No \\
\hline AT1G52230 & Photosystem I reaction center subunit VI-2/PSAH2 & 0.29 & $1.00 E+00$ & 0.95 & $0.00 E+00$ & -0.12 & $1.00 \mathrm{E}+00$ \\
\hline AT4G28750 & Photosystem I reaction center subunit IV A/PSAE1 & 0.01 & $1.00 E+00$ & 0.97 & $0.00 E+00$ & -0.10 & $1.00 E+00$ \\
\hline AT1G30380 & Photosystem I reaction center subunit psaK/PSAK & 0.12 & $1.00 E+00$ & 1.02 & $0.00 E+00$ & 0.04 & $1.00 E+00$ \\
\hline AT1G55670 & Photosystem I reaction center subunit V/PSAG & 0.31 & $1.00 \mathrm{E}+00$ & 1.27 & $0.00 E+00$ & -0.25 & $1.00 E+00$ \\
\hline \multicolumn{8}{|c|}{ Auxin responsive genes } \\
\hline AT5G57090 & Auxin efflux carrier PIN2 & 0.31 & $1.00 \mathrm{E}+00$ & 0.36 & $1.00 \mathrm{E}+00$ & 0.58 & $6.65 E-05$ \\
\hline AT4G12980 & Auxin-responsive AIR12-like protein & 0.35 & $1.00 E+00$ & 0.41 & $9.04 \mathrm{E}-01$ & 0.59 & 4.57E-05 \\
\hline AT3G25290 & Auxin-responsive AIR12-like protein & 0.26 & $1.00 E+00$ & 0.52 & $4.44 E-03$ & 0.79 & $1.66 \mathrm{E}-11$ \\
\hline AT1G04250 a & Indoleacetic acid-induced protein 17 (IAA17, AXR3) & 0.12 & $1.00 E+00$ & 0.55 & $7.79 E-04$ & 0.79 & $2.21 \mathrm{E}-11$ \\
\hline AT2G18010 & Auxin-responsive SAUR-like protein & 0.14 & $1.00 \mathrm{E}+00$ & 0.64 & $2.78 \mathrm{E}-06$ & 0.54 & $7.24 \mathrm{E}-04$ \\
\hline AT2G21210 & Auxin-responsive SAUR-like protein & 0.30 & $1.00 E+00$ & 0.62 & $1.40 E-05$ & 0.94 & $0.00 E+00$ \\
\hline AT3G23030 & Indoleacetic acid-induced protein 2 (IAA2) & 0.26 & $1.00 \mathrm{E}+00$ & 0.66 & $8.97 \mathrm{E}-07$ & 0.65 & $7.23 E-07$ \\
\hline AT4G17280 & Auxin-responsive AIR12-like protein & 0.27 & $1.00 \mathrm{E}+00$ & 0.68 & $2.20 \mathrm{E}-07$ & 0.85 & $0.00 E+00$ \\
\hline AT4G38840 & Auxin-responsive SAUR-like protein & 0.57 & $1.15 \mathrm{E}-04$ & 0.70 & $3.80 E-08$ & 0.73 & $2.12 \mathrm{E}-09$ \\
\hline AT4G38860 & Auxin-responsive SAUR-like protein & 0.15 & $1.00 E+00$ & 0.70 & $3.08 \mathrm{E}-08$ & 0.74 & $1.09 \mathrm{E}-06$ \\
\hline AT2G33830 & Dormancy/auxin associated family protein & 0.41 & $2.34 \mathrm{E}-01$ & 2.06 & $0.00 \mathrm{E}+00$ & 2.31 & $0.00 \mathrm{E}+00$ \\
\hline AT4G34770 & Auxin-responsive SAUR-like protein & 0.59 & $2.65 E-05$ & 0.44 & $4.03 E-01$ & 0.78 & $4.97 E-11$ \\
\hline AT3G04730 & Indoleacetic acid-induced protein 16 (IAA16) & 0.61 & 5.11E-06 & -0.36 & $1.00 \mathrm{E}+00$ & 0.82 & $0.00 E+00$ \\
\hline AT1G52830 ${ }^{\mathrm{a}}$ & Indoleacetic acid-induced protein 6 (IAA6,SHY1) & 0.71 & $5.50 E-09$ & 1.36 & $0.00 E+00$ & 1.28 & $0.00 E+00$ \\
\hline AT3G23050 ${ }^{\mathrm{a}}$ & Indoleacetic acid-induced protein 7 (IAA7, AXR2) & 0.71 & $4.90 E-09$ & 0.70 & $3.69 E-08$ & 1.01 & $0.00 E+00$ \\
\hline AT2G17500 & Putative auxin efflux carrier family protein & 0.72 & 2.77E-09 & 1.22 & $0.00 \mathrm{E}+00$ & 0.55 & $5.00 E-04$ \\
\hline AT4G34760 & Auxin-responsive SAUR-like protein & 0.77 & $2.77 \mathrm{E}-11$ & 0.79 & $1.57 \mathrm{E}-07$ & 0.48 & $2.39 E-02$ \\
\hline AT3G $15540^{\mathrm{a}}$ & Indoleacetic acid-induced protein 19 (IAA19, MSG2) & 0.79 & $5.53 \mathrm{E}-12$ & $\$$ & No & 0.79 & $1.66 \mathrm{E}-11$ \\
\hline \multicolumn{8}{|c|}{ Xyloglucan endotransglycosylases/hydrolases (XTH) } \\
\hline AT2G06850 & XTH-4 & 0.63 & $1.24 \mathrm{E}-06$ & 1.11 & $0.00 E+00$ & 0.59 & $4.89 \mathrm{E}-05$ \\
\hline \multicolumn{8}{|c|}{ Arabinogalactan proteins } \\
\hline AT4G16980 & Arabinogalactan-protein family & 1.42 & $0.00 \mathrm{E}+00$ & 1.92 & $0.00 E+00$ & 1.21 & $0.00 E+00$ \\
\hline AT5G53250 & Arabinogalactan-protein, putative (AGP22) & 0.97 & $0.00 E+00$ & 1.37 & $0.00 E+00$ & 1.14 & $0.00 E+00$ \\
\hline AT5G44130 & Fasciclin-like arabinogalactan-protein, putative & 0.50 & $4.99 \mathrm{E}-03$ & 0.76 & $6.95 \mathrm{E}-10$ & 1.28 & $0.00 E+00$ \\
\hline AT1G03870 & Fasciclin-like arabinogalactan-protein (FLA9) & 0.53 & $9.90 \mathrm{E}-04$ & 0.78 & $6.62 \mathrm{E}-11$ & 0.76 & $1.55 E-10$ \\
\hline AT5G10430 & Arabinogalactan-protein (AGP4) & 0.63 & $1.69 \mathrm{E}-06$ & 0.40 & $1.00 E+00$ & 0.90 & $0.00 E+00$ \\
\hline АТЗG13520 & Arabinogalactan-protein (AGP12) & 0.29 & $1.00 E+00$ & 0.68 & $2.46 \mathrm{E}-07$ & 0.47 & $3.63 E-02$ \\
\hline \multicolumn{8}{|c|}{ Pectin-metabolizing enzymes } \\
\hline AT2G43050 & Pectin methyl-esterase & 0.21 & $1.00 \mathrm{E}+00$ & 0.35 & $1.00 \mathrm{E}+00$ & 0.86 & $0.00 E+00$ \\
\hline АT3G06770 & Polygalacturonase & 0.20 & $1.00 E+00$ & 0.93 & $0.00 E+00$ & 0.31 & $1.00 E+00$ \\
\hline AT4G33220 & Pectin methyl-esterase & 0.48 & $1.60 \mathrm{E}-02$ & 0.65 & $1.42 \mathrm{E}-06$ & 0.33 & $1.00 \mathrm{E}+00$ \\
\hline AT4G24780 & Pectate lyase family protein & 0.53 & $1.33 E-03$ & 0.61 & $2.07 E-05$ & 0.34 & $1.00 E+00$ \\
\hline AT5G64620 & Pectin methyl-esterase inhibitor & 0.41 & $6.50 E-01$ & 0.78 & $1.10 E-10$ & 0.47 & $4.03 E-02$ \\
\hline AT3G07010 & Pectate lyase family protein & 0.35 & $1.00 \mathrm{E}+00$ & 0.78 & $7.17 E-11$ & 0.51 & $5.22 \mathrm{E}-03$ \\
\hline АТ3G49220 & Pectin methyl-esterase & 0.33 & $1.00 E+00$ & 0.69 & $1.26 \mathrm{E}-07$ & 0.52 & $2.37 \mathrm{E}-03$ \\
\hline AT4G25260 b & Pectin methyl-esterase inhibitor & 0.74 & $6.36 \mathrm{E}-10$ & 0.82 & $5.52 E-12$ & 0.74 & $9.56 \mathrm{E}-10$ \\
\hline AT5G63180 & Pectate lyase family protein & 0.25 & $1.00 E+00$ & 0.59 & $8.73 E-05$ & 0.79 & $2.21 \mathrm{E}-11$ \\
\hline AT1G53830 & Pectin methyl-esterase & 0.14 & $1.00 \mathrm{E}+00$ & 0.74 & $2.81 \mathrm{E}-09$ & 0.79 & $1.66 \mathrm{E}-11$ \\
\hline AT1G23205 & Pectin methyl-esterase inhibitor & 0.42 & $2.75 \mathrm{E}-01$ & 0.96 & $0.00 \mathrm{E}+00$ & 1.05 & $0.00 E+00$ \\
\hline AT4G25250 & Pectin methyl-esterase inhibitor (PMEI4) & 0.08 & $1.00 \mathrm{E}+00$ & 1.25 & $0.00 \mathrm{E}+00$ & 1.58 & $0.00 E+00$ \\
\hline \multicolumn{8}{|l|}{ Expansins } \\
\hline AT4G38400 b & Expansin family protein (EXPL2) & 0.73 & $9.63 \mathrm{E}-10$ & 0.85 & $0.00 E+00$ & 0.48 & $2.34 \mathrm{E}-02$ \\
\hline AT2G40610 & Expansin, putative (EXP8) & 0.67 & 8.17E-08 & 1.06 & $0.00 E+00$ & 1.08 & $0.00 E+00$ \\
\hline AT1G20190 b & Expansin, putative (EXP11) & 0.66 & $2.40 \mathrm{E}-07$ & 0.28 & $1.00 E+00$ & 0.94 & $0.00 E+00$ \\
\hline AT2G28950 & Expansin, putative (EXP6) & 0.57 & $8.76 \mathrm{E}-05$ & -0.16 & $1.00 E+00$ & 0.68 & $6.65 \mathrm{E}-08$ \\
\hline
\end{tabular}

Genes involved in photosynthesis, auxin or cell wall metabolism that were upregulated (Bonferoni $P$-value $<10^{-4}$ ) over the $45-55$ hpi period are shown. $\log _{2}$ ratios and Bonferoni $P$-values are shown.

${ }^{a}$ Auxin responsive genes for which gain of function mutants exist with reduced hypocotyl growth in the dark (references in text).

${ }^{b}$ Genes encoding proteins identified in the hypocotyl cell wall (Jamet et al., 2008). Colors refer to the pseudocolor scale of Table S1.

$\$$ : grey color refers to missing values. 


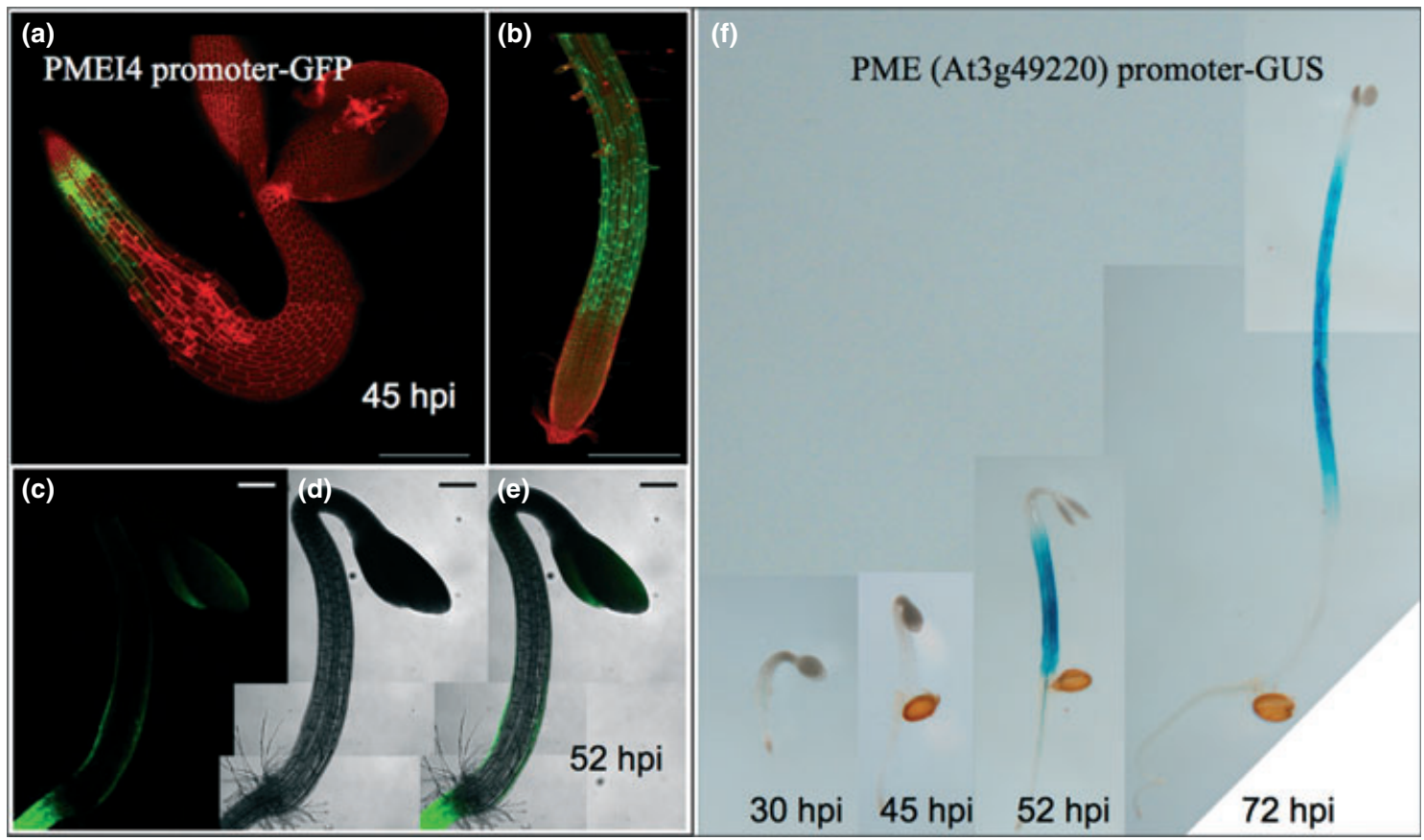

Fig. 3. Upregulation of genes involved in pectin metabolism during the growth acceleration. (a-e) Green fluorescent protein (GFP) expression from the pectin methyl esterase inhibitor (PMEI)4 (At4g25250) promoter. Dark-grown seedling at $45 \mathrm{~h}$ after induction (hpi) (a) and $52 \mathrm{hpi}$ (c-e), and light-grown root (b). GFP fluorescence in green $(a, b, c, e)$, propidium iodide plasma membrane labeling in red (a,b), Nomarski image (d) and overlay of (c) and (d) (e). Z-stack of confocal optical sections (a,b) and single optical section half-way through the hypocotyl (c). Note the epidermis-specific expression. F: ß-glucuronidase expression from pectin methylesterase (PME) (At3g49220) promoter at 30, 45, 52 and 72 hpi. Scale bar $=200 \mu \mathrm{m}$.

line showed a slow elongation rate for the first $46-47 \mathrm{hpi}$, after which the growth rate increased to reach a plateau at $0.3 \mathrm{~mm} \mathrm{~h}^{-1}$. It should be noted that in these experiments seedlings were grown between the agar surface and a nylon mesh to maintain the hypocotyl within the focal plane of the camera. This explains why the acceleration period was about twice as long as in the conditions used for the microarray analysis. Interestingly, in these conditions, the onset of the growth acceleration was delayed by $3 \mathrm{~h}$ and $5 \mathrm{~h}$ with pPMEI4::GFP and p35S::PMEI4:GFP, respectively, suggesting a dose-dependent role for pectin de-methylesterification in the timing of the growth acceleration. Interestingly, the slope of the curve, that is, the actual acceleration rate, was comparable to that of the control plants suggesting that pectin de-methylesterification plays a role in the timing of the growth transition but not the cell expansion rate per se.

\section{Discussion}

Previous studies have shown that cell elongation in the dark-grown Arabidopsis hypocotyl is biphasic, with a slow growth phase, during which a thick polylamellated wall is deposited and a rapid growth phase during which a massive rearrangement and thinning of the cell wall takes place (Refrégier et al., 2004; Derbyshire et al., 2007a). Here, we observed that concomitant with the growth acceleration, the hypocotyl cells acquired insensitivity to the inhibition of cellulose synthesis by isoxaben (Refrégier et al., 2004). This shows that only during the slow growth phase is cell elongation coordinated with cellulose synthesis, presumably through a feedback mechanism involving putative cell wall sensors such as the receptor kinase THESEUS1 (Hematy et al., 2007). During the growth acceleration, however, cell elongation becomes uncoupled from cellulose synthesis through an unknown mechanism indicating a qualitative change in the control of cell elongation. The reproducible changes in the ratio between wall polymers that occurred just before and during, but not after the growth acceleration, and the observed changes in gene expression further corroborate that the hypocotyl cells undergo a developmental transition during the growth acceleration. The gene ontology categories of the differentially expressed genes provide insights into the processes that accompany this transition. First, ribosomal protein transcript levels diminished $c$. twofold during the transition. This illustrates quite dramatically that cytoplasm synthesis and growth are coupled only during the very early stages of cell expansion and that the bulk of cell growth must be the result of water and solute uptake in the vacuole without further increase in the amount of cytoplasm (Sugimoto-Shirasu \& Roberts, 2003). Second, in contrast to a previous report (Jensen et al., 

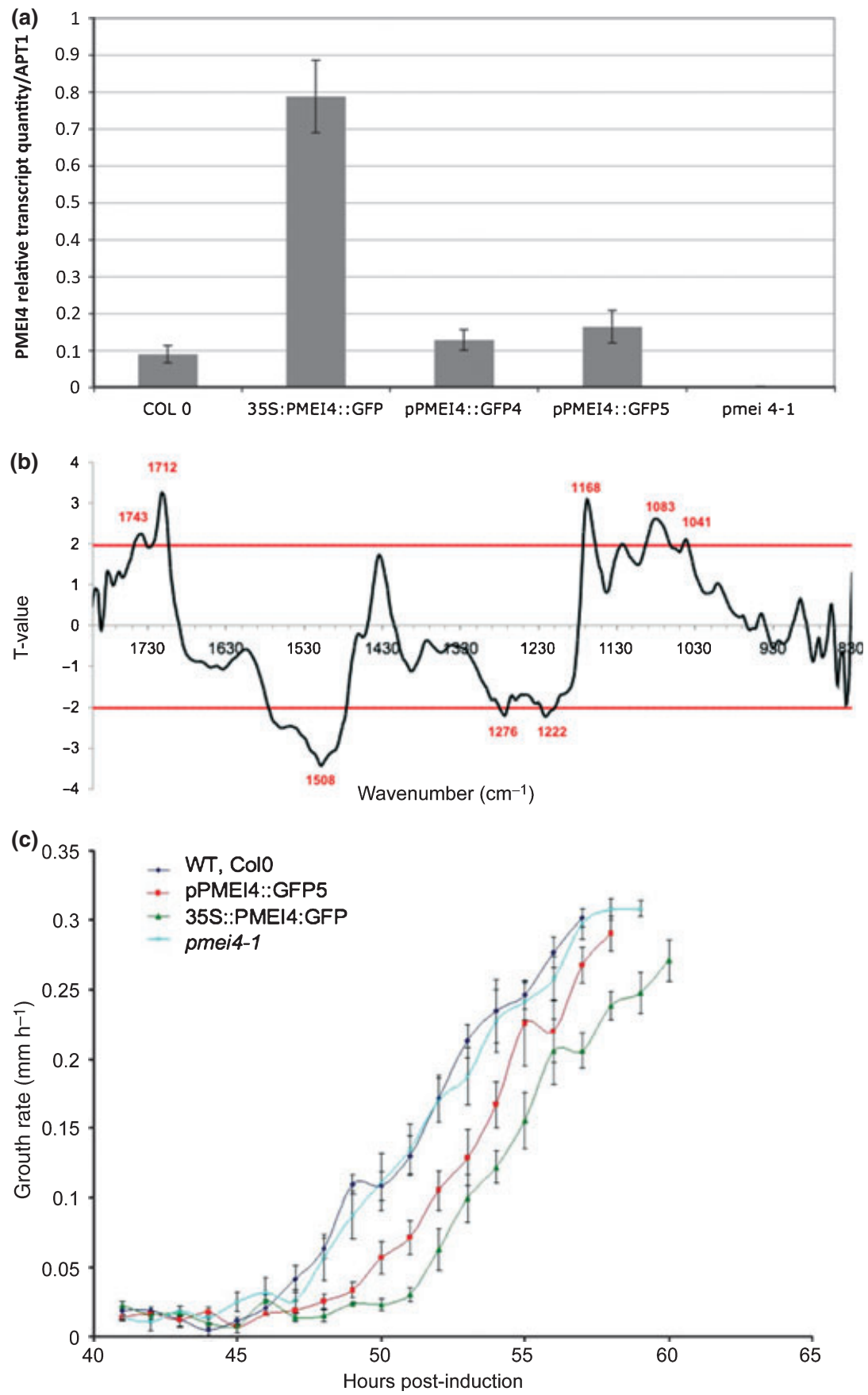

Fig. 4. Overexpression of pectin methylesterase inhibitor (PMEI)4 delays growth acceleration. (a) Quantitative reversetranscription polymerase chain reaction (RT-PCR) shows strongly increased PMEI4 transcript levels, compared with Col0, in a line expressing PMEI4 from the 35 S promoter (p35S::PMEI4:GFP (green fluorescent protein)) and a smaller increase in lines expressing PMEI4 from its own promoter (pPMEl::GFP4 and 5). pmei4-1 is a null mutant. (b) Student's $t$-test on average Fourier transform infrared (FT-IR) spectra from 4-d-old dark-grown hypocotyls of PPMEI4::GFP (line 4 and 5) and p35S::PMEI4:GFP (spectra from all overexpression lines were pooled) compared with spectra from ColO WT controls. Horizontal red lines indicate limits of $95 \%$ confidence interval. Note the significant peak at $1712 \mathrm{~cm}^{-1}$ indicating the increased levels of an ester bond in PMEI4 overexpression lines, consistent with reduced pectin methylesterase (PME) activity. (c) Growth rate measured using kinematic analysis of dark-grown hypocotyl growth. The acceleration is delayed by $3 \mathrm{~h}$ and $5 \mathrm{~h}$, respectively in lines expressing PMEI4 from its own or the 355 promoter. No difference is observed between $\mathrm{ColO}$ and the PMEI4 knock out line.
1998), which claimed that auxin transport is not required for dark-grown hypocotyl elongation, the expression data suggest a role for auxin signaling in the growth acceleration. Indeed, 20 auxin-regulated genes were upregulated during the growth acceleration. In addition, for at least three of those genes (IAA6/SHY1,IAAT/AXR2, IAA17/AXR3), gain of function mutants, in which auxin signaling is repressed (Overvoorde et al., 2005), did not show growth acceleration during dark-grown hypocotyl development (data not shown). Among the auxin-upregulated genes, IAA19/MSG2 encodes a negative regulator of the transcriptional regulator ARF7 (Tatematsu et al., 2004), which was not differentially expressed at the transcript level in our study. Upon auxintriggered turnover of IAA19/MSG2, ARF7 positively regulates expansin EXP8 (Esmon et al., 2006), a gene, which also, in this study, was upregulated during the growth acceleration. Mutant analysis will show to what extent the upregulation of EXP8 is critical for the growth acceleration. Third, genes encoding other wall-modifying proteins were also over-represented among the upregulated 
genes. This included other expansins, XTHs, AGPs and 12 enzymes involved in pectin modification. Several lines of evidence support a role for pectin de-methylesterification in the growth acceleration. The reduction in the amount of ester bonds, observed by FT-IR microspectroscopy, is consistent with the de-methylesterification and degradation of HG during the growth acceleration. Also, the delay of the growth acceleration in the hypocotyl by the overexpression of PMEI4 suggests that pectin de-methylesterification is involved in triggering this event. Interestingly, once the acceleration was initiated, the hypocotyls of the PMEI4 overexpression lines showed the same acceleration rate as the wild type, suggesting that pectin de-methylesterification only controls the initiation of the acceleration but not the growth process itself. Pectin de-methylesterification and turnover has been observed in other growing organs and has been suggested to play a role in growth control (Derbyshire et al., 2007b; Wolf et al., 2009). The results of this study specify this role, at least in dark-grown hypocotyls, in the control of the timing of the onset of the growth acceleration. Interestingly, we have recently observed a similar key role for pectin de-methylesterification in triggering organ initiation in the apical meristem (Peaucelle et al., 2008). It is not clear how the de-methylesterification of $\mathrm{HG}$ may contribute to triggering the growth acceleration. This may involve the acidification of the wall (Bosch et al., 2005) and as a result the activation of expansins and/or other remodeling factors (Cosgrove, 1999). Alternatively, the cleavage and/or turnover of de-methylesterified pectin may decrease the cell wall viscosity or increase its porosity (Cosgrove, 1999). Finally, oligogalacturonides with signaling activity may also be generated (Ridley et al., 2001). It is interesting to note that PMEI4 was specifically expressed in the hypocotyl epidermis, which is consistent with the key role for the epidermis in the control of organ growth (Savaldi-Goldstein et al., 2007).

In conclusion, this study provides new insights into the regulation of cell elongation in the dark-grown hypocotyl. It is conceivable that in other organs, a similar succession of cellular events take place. A major challenge will be to understand how environmental and endogenous stimuli impinge on these distinct growth stages to control organ growth. The molecular markers identified in this study will be useful for the dissection of the response of plant organs to these stimuli.

\section{Acknowledgements}

The GWB3 and GWB4 Gateway binary vectors were kindly supplied by Tsuyoshi Nakagawa (Shimane University, Japan). Gerrit Beemster and Alexis Peaucelle are thanked for their help in establishing the method for kinematic analysis. The work was financed in part by grants ACI BCMS195 and ANR BLAN06-2_141830 (IMACEL) from the French Ministry of Research and Technology and the EU FP6 grants 028974 (CASPIC) and 037704 (AGRONOMICS) to HH. Part of the work of $\mathrm{HH}$ was carried out during a stay at the VIB in Ghent financed by a grant from the University of Ghent. JVO. was funded by a PhD grant of the Institute for the Promotion of Innovation through Science and Technology in Flanders (IWT, Vlaanderen). JVO and KV acknowledge the financial support of the Research Foundation, Flanders (FWO, Vlaanderen), the Interuniversity Attraction Poles Program-Belgian StateBelgian Science Policy [IUAP VI/33] and the University of Antwerp (BOF-IWS). V.B. is financed by a DFG grant BI $1417 / 1-1$.

\section{References}

Achard P, Renou JP, Berthome R, Harberd NP, Genschik P. 2008 Plant dellas restrain growth and promote survival of adversity by reducing the levels of reactive oxygen species. Current Biology 18: 656-660.

An SH, Sohn KH, Choi HW, Hwang IS, Lee SC, Hwang BK. 2008. Pepper pectin methylesterase inhibitor protein capmeil is required for antifungal activity, basal disease resistance and abiotic stress tolerance. Planta 228: 61-78.

Anderson CT, Carroll A, Akhmetova L, Somerville C. 2009. Real-time imaging of cellulose reorientation during cell wall expansion in Arabidopsis roots. Plant Physiology 152: 787-796.

Bechtold N, Pelletier G. 1998. In planta Agrobacterium-mediated transformation of adult Arabidopsis thaliana plants by vacuum infiltration. Methods in Molecular Biology 82: 259-266.

Besson-Bard A, Gravot A, Richaud P, Auroy P, Duc C, Gaymard F, Taconnat L, Renou JP, Pugin A, Wendehenne D. 2009. Nitric oxide contributes to cadmium toxicity in Arabidopsis by promoting cadmium accumulation in roots and by up-regulating genes related to iron uptake. Plant Physiology 149: 1302-1315.

Birnbaum K, Shasha DE, Wang JY, Jung JW, Lambert GM, Galbraith DW, Benfey PN. 2003. A gene expression map of the Arabidopsis root. Science 302: 1956-1960.

Bosch M, Cheung AY, Hepler PK. 2005. Pectin methylesterase, a regulator of pollen tube growth. Plant Physiology 138: 1334-1346.

Carpita N, McCann M. 2000. The cell wall. In: Buchanan B, Gruissem W, Jones R, eds. Biochemistry \& molecular biology of plants. Rockville, MD, USA: ASPB, 52-108.

Cosgrove DJ. 1999. Enzymes and other agents that enhance cell wall extensibility. Annual Review of Plant Physiology and Plant Molecular Biology 50: 391-417.

Crowe ML, Serizet C, Thareau V, Aubourg S, Rouze P, Hilson P, Beynon J, Weisbeek P, van Hummelen P, Reymond P et al. 2003. CATMA: a complete Arabidopsis GST database. Nucleic Acids Research 31: 156-158.

Crowell EF, Bischoff V, Desprez T, Rolland A, Stierhof YD, Schumacher K, Gonneau M, Hofte H, Vernhettes S. 2009. Pausing of Golgi bodies on microtubules regulates secretion of cellulose synthase complexes in Arabidopsis. Plant Cell 21: 1141-1154.

Derbyshire P, Findlay K, McCann MC, Roberts K. 2007a. Cell elongation in Arabidopsis hypocotyls involves dynamic changes in cell wall thickness. Journal of Experimental Botany 58: 2079-2089.

Derbyshire P, McCann MC, Roberts K. 2007b. Restricted cell elongation in Arabidopsis hypocotyls is associated with a reduced average pectin esterification level. BMC Plant Biology 7: 31.

Desprez T, Vernhettes S, Fagard M, Refregier G, Desnos T, Aletti E, Py N, Pelletier S, Hofte H. 2002. Resistance against herbicide isoxaben 
and cellulose deficiency caused by distinct mutations in same cellulose synthase isoform CESA6. Plant Physiology 128: 482-490.

Esmon CA, Tinsley AG, Ljung K, Sandberg G, Hearne LB, Liscum E. 2006. A gradient of auxin and auxin-dependent transcription precedes tropic growth responses. Proceedings of the National Academy of Sciences, USA 103: 236-241.

Fagard M, Desnos T, Desprez T, Goubet F, Refregier G, Mouille G, McCann M, Rayon C, Vernhettes S, Hofte H. 2000. Procuste1 encodes a cellulose synthase required for normal cell elongation specifically in roots and dark-grown hypocotyls of Arabidopsis. Plant Cell 12: 2409-2424.

Gagnot S, Tamby JP, Martin-Magniette ML, Bitton F, Taconnat L, Balzergue S, Aubourg S, Renou JP, Lecharny A, Brunaud V. 2008. CATdb: a public access to Arabidopsis transcriptome data from the URGV-CATMA platform. Nucleic Acids Research 36: D986-D990.

Ge Y, Dudoit S, Speed TP. 2003. Resampling-based multiple testing for microarray data analysis. TEST 12: 1-44.

Gendreau E, Traas J, Desnos T, Grandjean O, Caboche M, Hofte H. 1997. Cellular basis of hypocotyl growth in Arabidopsis thaliana [in process citation]. Plant Physiology 114: 295-305.

Gutierrez R, Lindeboom JJ, Paredez AR, Emons AM, Ehrhardt DW. 2009. Arabidopsis cortical microtubules position cellulose synthase delivery to the plasma membrane and interact with cellulose synthase trafficking compartments. Nature Cell Biology 11: 797-806.

Hematy K, Sado PE, Van Tuinen A, Rochange S, Desnos T, Balzergue S, Pelletier S, Renou JP, Hofte H. 2007. A receptor-like kinase mediates the response of Arabidopsis cells to the inhibition of cellulose synthesis. Current Biology 17: 922-931.

Hilson P, Allemeersch J, Altmann T, Aubourg S, Avon A, Beynon J, Bhalerao RP, Bitton F, Caboche M, Cannoot B et al. 2004. Versatile gene-specific sequence tags for Arabidopsis functional genomics: transcript profiling and reverse genetics applications. Genome Research 14: 2176-2189.

Irshad M, Canut H, Borderies G, Pont-Lezica R, Jamet E. 2008. A new picture of cell wall protein dynamics in elongating cells of Arabidopsis thaliana: confirmed actors and newcomers. BMC Plant Biology 8: 94.

Jamet E, Albenne C, Boudart G, Irshad M, Canut H, Pont-Lezica R. 2008. Recent advances in plant cell wall proteomics. Proteomics 8: 893908.

Jensen PJ, Hangarter RP, Estelle M. 1998. Auxin transport is required for hypocotyl elongation in light-grown but not dark-grown Arabidopsis. Plant Physiology 116: 455-462.

Kacurakova M, Smith AC, Gidley MJ, Wilson RH. 2002.

Molecular interactions in bacterial cellulose composites studied by $1 \mathrm{~d} \mathrm{ft-}$ ir and dynamic 2d ft-ir spectroscopy. Carbohydrate Research 337: 11451153.

Karimi M, Inze D, Depicker A. 2002. Gateway vectors for Agrobacteriummediated plant transformation. Trends in Plant Science 7: 193-195.

Koncz C, Schell J. 1986. The promoter of the tl-DNA gene 5 controls the tissue-specific expression of chimaeric genes carried by a novel type of Agrobacterium binary vector. Molecular \& General Genetics 204: 383396.

Krinke O, Flemr M, Vergnolle C, Collin S, Renou JP, Taconnat L, Yu A, Burketova L, Valentova O, Zachowski A et al. 2009. Phospholipase D activation is an early component of the salicylic acid signaling pathway in Arabidopsis cell suspensions. Plant Physiology 150: 424-436.

Lurin C, Andres C, Aubourg S, Bellaoui M, Bitton F, Bruyere C, Caboche M, Debast C, Gualberto J, Hoffmann B et al. 2004. Genome-wide analysis of Arabidopsis pentatricopeptide repeat proteins reveals their essential role in organelle biogenesis. Plant Cell 16: 20892103.

Maere S, Heymans K, Kuiper M. 2005. Bingo: a cytoscape plugin to assess overrepresentation of gene ontology categories in biological networks. Bioinformatics 21: 3448-3449.
Mouille G, Robin S, Lecomte M, Pagant S, Hofte H. 2003. Classification and identification of Arabidopsis cell wall mutants using fouriertransform infrared (ft-ir) microspectroscopy. Plant Journal 35: 393-404.

Murashige T, Skoog F. 1962. Revised medium for rapid growth and bioassays with tobacco tissue cultures. Physiologia Plantarum 15: 473497.

Nemhauser JL, Hong F, Chory J. 2006. Different plant hormones regulate similar processes through largely nonoverlapping transcriptional responses. Cell 126: 467-475.

Overvoorde PJ, Okushima Y, Alonso JM, Chan A, Chang C, Ecker JR, Hughes B, Liu A, Onodera C, Quach H et al. 2005. Functional genomic analysis of the auxin/indole-3-acetic acid gene family members in Arabidopsis thaliana. Plant Cell 17: 3282-3300.

Peaucelle A, Louvet R, Johansen JN, Hofte H, Laufs P, Pelloux J, Mouille G. 2008. Arabidopsis phyllotaxis is controlled by the methylesterification status of cell-wall pectins. Current Biology 18: 1943-1948.

Pelloux J, Rusterucci C, Mellerowicz EJ. 2007. New insights into pectin methylesterase structure and function. Trends in Plant Science 12: $267-$ 277.

Peng X, Wood CL, Blalock EM, Chen KC, Landfield PW, Stromberg AJ. 2003. Statistical implications of pooling rna samples for microarray experiments. BMC Bioinformatics 4: 26.

Refrégier G, Pelletier S, Jaillard D, Hofte H. 2004. Interaction between wall deposition and cell elongation in dark-grown hypocotyl cells in Arabidopsis. Plant Physiology 135: 959-968.

Ridley BL, O’Neill MA, Mohnen D. 2001. Pectins: structure, biosynthesis, and oligogalacturonide-related signaling. Phytochemistry 57: 929-967.

Rockel N, Wolf S, Kost B, Rausch T, Greiner S. 2008. Elaborate spatial patterning of cell-wall PME and PMEI at the pollen tube tip involves PMEI endocytosis, and reflects the distribution of esterified and deesterified pectins. Plant Journal 53: 133-143.

Rose JK, Braam J, Fry SC, Nishitani K. 2002. The xth family of enzymes involved in xyloglucan endotransglucosylation and endohydrolysis: current perspectives and a new unifying nomenclature. Plant and Cell Physiology 43: 1421-1435.

Savaldi-Goldstein S, Peto C, Chory J. 2007. The epidermis both drives and restricts plant shoot growth. Nature 446: 199-202.

Scheible WR, Eshed R, Richmond T, Delmer D, Somerville C. 2001. Modifications of cellulose synthase confer resistance to isoxaben and thiazolidinone herbicides in Arabidopsis Ixr1 mutants. Proceedings of the National Academy of Sciences, USA 98: 10079-10084.

Seifert GJ, Roberts K. 2007. The biology of arabinogalactan proteins. Annual Review of Plant Physiology 58: 137-161.

Silk WK, Erickson RO. 1979. Kinematics of plant growth. Journal of Theoretical Biology 76: 481-501.

Sugimoto-Shirasu K, Roberts K. 2003. 'Big it up': endoreduplication and cell-size control in plants. Current Opinion in Plant Biology 6: 544-553.

Taiz L. 1984. Plant cell expansion: regulation of cell wall mechanical properties. Annual Review of Plant Physiology 35: 585-657.

Tatematsu K, Kumagai S, Muto H, Sato A, Watahiki MK, Harper RM, Liscum E, Yamamoto KT. 2004. Massugu2 encodes aux/iaa19, an auxin-regulated protein that functions together with the transcriptional activator nph4/arf7 to regulate differential growth responses of hypocotyl and formation of lateral roots in Arabidopsis thaliana. Plant Cell 16: 379-393.

Thareau V, Dehais P, Serizet C, Hilson P, Rouze P, Aubourg S. 2003. Automatic design of gene-specific sequence tags for genome-wide functional studies. Bioinformatics 19: 2191-2198.

Willats WG, McCartney L, Mackie W, Knox JP. 2001a. Pectin: cell biology and prospects for functional analysis. Plant Molecular Biology 47 : 9-27.

Willats WG, Orfila C, Limberg G, Buchholt HC, van Alebeek GJ, Voragen AG, Marcus SE, Christensen TM, Mikkelsen JD, Murray BS 
et al. 2001b. Modulation of the degree and pattern of methylesterification of pectic homogalacturonan in plant cell walls. Implications for pectin methyl esterase action, matrix properties, and cell adhesion. Journal of Biological Chemistry 276: 19404-19413.

Willats WG, Steele-King CG, Marcus SE, Knox JP. 1999. Side chains of pectic polysaccharides are regulated in relation to cell proliferation and cell differentiation. Plant Journal 20: 619-628.

Wolf S, Mouille G, Pelloux J. 2009. Homogalacturonan methylesterification and plant development. Molecular Plant 2: 851-860.

Yang YH, Dudoit S, Luu P, Lin DM, Peng V, Ngai J, Speed TP. 2002.

Normalization for cDNA microarray data: a robust composite method addressing single and multiple slide systematic variation. Nucleic Acids Research 30: e15.

\section{Supporting Information}

Additional supporting information may be found in the online version of this article.

Fig. S1 Phenotype of wild-type dark-grown seedlings before (45 h after induction (hpi) and $48 \mathrm{hpi}$ ) and after (52 hpi and $55 \mathrm{hpi}$ ) the growth acceleration of the hypocotyl.

Fig. S2 Isoxaben treatment triggers the internalization of GFP-CESA3 both before and after the growth acceleration.
Fig. S3 Transcriptome analysis: experimental design and overview of the results.

Fig. S4 Over-represented gene categories among the genes that were differentially regulated during the $45-55 \mathrm{~h}$ after induction (hpi) interval.

Table S1 Differentially expressed genes during the time course and upon isoxaben treatment

Table S2 Validation by quantitative reverse transcriptase PCR (Q-RT-PCR) of 30 differentially expressed genes during the $45-55 \mathrm{~h}$ after induction (hpi) interval

Table S3 Downregulation of ribosomal protein genes during the $45-55 \mathrm{~h}$ after induction (hpi) interval in darkgrown hypocotyls

Please note: Wiley-Blackwell are not responsible for the content or functionality of any supporting information supplied by the authors. Any queries (other than missing material) should be directed to the New Phytologist Central Office.

\section{About New Phytologist}

- New Phytologist is owned by a non-profit-making charitable trust dedicated to the promotion of plant science, facilitating projects from symposia to open access for our Tansley reviews. Complete information is available at www.newphytologist.org.

- Regular papers, Letters, Research reviews, Rapid reports and both Modelling/Theory and Methods papers are encouraged. We are committed to rapid processing, from online submission through to publication 'as-ready' via Early View - our average submission to decision time is just 29 days. Online-only colour is free, and essential print colour costs will be met if necessary. We also provide 25 offprints as well as a PDF for each article.

- For online summaries and ToC alerts, go to the website and click on 'Journal online'. You can take out a personal subscription to the journal for a fraction of the institutional price. Rates start at $£ 151$ in Europe/\$279 in the USA \& Canada for the online edition (click on 'Subscribe' at the website).

- If you have any questions, do get in touch with Central Office (newphytol@lancaster.ac.uk; tel +44 1524 594691) or, for a local contact in North America, the US Office (newphytol@ornl.gov; tel +1 865576 5261). 